\title{
Challenges and perspectives of mothers of children with microcephaly due to Zika virus infection
}

\author{
Desafios e perspectivas de mães de crianças com microcefalia pelo vírus Zika
}

Mara Marusia Martins Sampaio Campos ${ }^{1}$, Thaynara Campos de Sousa ${ }^{1}$, Gianini Portela Teixeira ${ }^{1}$, Kellen Yamille dos Santos Chaves ${ }^{2}$, Maria Valdeleda Uchoa Moraes Araújo ${ }^{1}$, Marília Rocha Sousa ${ }^{1}$

Objective: to understand the challenges and perspectives of mothers of children with microcephaly due to Zika virus infection. Methods: qualitative study carried out with twelve mothers of children with microcephaly due to Zika virus at a pediatric public hospital. Data were collected through a semi-structured interview and submitted to content analysis. Results: the speeches revealed the mothers were mostly unaware of the occurrence of Zika virus infection in pregnancy, and the moment of diagnosis was characterized by surprise and suffering, despite the observed overcoming. Many of them did not know the meaning of microcephaly and did not know what changes and limitations their children might have. In describing the difficulties in caring for the child, mothers attached to spirituality as a form of coping. Conclusion: microcephaly brought a new reality to the investigated women, who sometimes denied their own reality, demonstrating in the speeches many challenges and few perspectives.

Descriptors: Zika Virus; Mothers; Microcephaly; Child.

Objetivo: compreender desafios e perspectivas de mães de crianças com microcefalia pelo vírus Zika. Métodos: estudo qualitativo, realizado com doze mães de crianças com microcefalia pelo vírus Zika, em hospital público pediátrico. Dados coletados por meio de entrevista semiestruturada, os quais foram submetidos à análise de conteúdo. Resultados: de acordo com as falas, as mães, em maioria, desconheciam a ocorrência de vírus Zika na gestação, sendo o momento do diagnóstico caracterizado por surpresa e sofrimento, apesar da superação observada. Muitas delas não sabiam o significado de microcefalia, bem como desconheciam as alterações e limitações que as crianças poderiam apresentar. Ao descrever as dificuldades no cuidado com o filho, revelaram que usavam a espiritualidade como forma de enfrentamento. Conclusão: a microcefalia trouxe, de tal forma, nova realidade para as mulheres investigadas, que, por vezes, negavam a própria realidade, demonstrando, nas falas, muitos desafios e poucas perspectivas.

Descritores: Zika Vírus; Mães; Microcefalia; Criança.

\footnotetext{
${ }^{1}$ Centro Universitário Christus. Fortaleza, CE, Brazil.

${ }^{2}$ Maternidade Escola Assis Chateaubriand. Fortaleza, CE, Brazil.
} 


\section{Introduction}

By April 2015, there was the first transmission of the Zika virus (ZIKV) in Brazil, reaching more than one million people infected. With this outbreak, there was a concomitant increase in the number of cases of microcephaly in Brazil, in which 1,248 suspected cases were identified, representing a 20 -fold increase over the last years $^{(1)}$. From 2000 to 2014, 2,464 live births with microcephaly were recorded in Brazil, with an annual average of 164 cases; while in 2015 the number of cases increased by nine times in relation to this average, totaling 1,608 cases, of which $71.0 \%$ were children of women living in the Northeast of Brazil, which created an epidemic of microcephaly ${ }^{2)}$.

After evaluation and study of the cases cited, the relationship between the ZIKV and the microcephaly in the country was consolidated, writing a new chapter in the history of Medicine. Thus, new concepts and risks related to congenital infections, previously non-existent, have emerged and raised the possibility of a mosquito transmit an etiologic agent that causes malformations. Until then, only those caused by viruses, bacteria and protozoa were known, such as those that are part of syphilis, toxoplasmosis, rubella, cytomegalovirus and herpes virus and others, with high teratogenic power and great risk of malformations in the fetus ${ }^{(3-4)}$.

Microcephaly is described as a type of congenital malformation characterized by a cephalic perimeter inferior to that expected for age and gender. The long-term consequences depend on fundamental brain abnormalities and can range from mild delays in development to intellectual and motor deficits, such as cerebral palsy ${ }^{(4)}$. In general, children with microcephaly associated with ZIKV present a significant delay in neuropsychomotor development associated with visual, auditory and sensory alterations, which directly impact on functional independence and social insertion $^{(5)}$.

Studies on microcephaly related to the ZIKV have described that, according to the current structu- re, mothers and their children with this malformation are prone to a life of great difficulties, since these women have to take time off from work as there are no institutions adequate to receive these children. This is because in Brazil, to date, there is no infrastructure capable of accommodating these children and families to guarantee their survival with a minimum level of dignity $^{(6)}$.

The diagnosis of a disease at the birth of a child causes the parents to seek ways of dealing with the novelty, generating a series of reactions and feelings arising from the rupture of the dream of the idealized child to a "sick" child, which is the real thing. It is the moment to deconstruct an expectation, in which each person has a particular form of confrontation ${ }^{(7)}$.

The knowledge of the perception of mothers of children with microcephaly due to the ZIKV about the challenges faced and their perspectives contributes to multiprofessional health care, strengthening the theory that care must be global, not only considering the biological aspect, but always valuing the human and subjective dimension of these mothers who have, particularly, doubts and longings, which reflects on the health of the child. In this perspective, the question that guided the study was: What are the challenges and the perspectives of mothers of children with microcephaly due to the Zika virus?

The objective of the present study was to understand the challenges and perspectives of mothers of children with microcephaly due to the ZIKV.

\section{Methods}

This was a qualitative research carried out in a public hospital reference in the tertiary care of children and adolescents in Fortaleza, Ceará, Brazil, which is specialized in the treatment of severe and highly complex pediatric diseases, as well as in teaching and research, offering a diversity of services, such as the outpatient clinic with 28 specialties, including neurogenetics for children with microcephaly due to ZIKV. This outpatient clinic has a multiprofessional team, 
consisting of a physician, a nurse and a physiotherapist, who make the diagnosis, the clinical evaluation, the reception, as well as the motor development assistance, respectively.

The sample of this study was for convenience, being investigated 12 mothers until there was theoretical saturation of the information. The women who accepted to participate in the study were older/equalto 18 years old and mothers of children with medical diagnosis of microcephaly due to ZIKV, who were in multiprofessional treatment in the study hospital. The research subjects were approached by the physiotherapist researcher in the waiting room of the outpatient clinic, individually and informally, and were informed about the study and invited to participate. Participation and data collection only occurred after the participants signed the Informed Consent Form.

Data were collected from October 2017 to January 2018 through a semistructured interview and application of questionnaires for sociodemographic characterization (age, marital status, family income, schooling, origin) and pre- and perinatal history (use of teratogens, prenatal care, occurrence of infections and parity).

After that, it was started an interview with the following guiding question: Does your child have microcephaly? The other questions that followed were: How did you feel at the time of diagnosis? What do you know about this disease? Have you received any guidance about the care taken for the disease? What is the most difficult thing with your child on a daily basis? Does your child have any changes, in your perception? What do you think about the future of your child? The sequence of questions was conducted so that, at the end of the study, it was possible to categorize the speeches into three blocks: The moment of diagnosis: being the mother of a special child; Getting to know microcephaly: the unknown; and Living with the disease: full dedication, mothering.

The interviews were recorded in a voice recorder, and the speeches were transcribed literally, that is, with fidelity and particularities. The data were analyzed according to the method of content analysis, by following the steps: comprehensive reading of the material, exploration of the material and elaboration of interpretative synthesis ${ }^{(8)}$. Participants signed a term allowing the recording of the interview and, in order to safeguard the anonymity of the mothers involved in the research, pseudonyms related to names of gemstones were used: Pearl, Agate, Moonstone, Jade, Jasper, Olivine, Turquoise, Blue Tourmaline, Ruby, Emerald, Diamond and Sapphire.

The study respected the formal and ethical requirements and only began after the approval of the ethics committee of the study hospital, according to opinion no 2,198,698.

\section{Results}

On the characterization of the 12 mothers participating in the study, the ages ranged from 18 to 38 years, in which half were single $(6 ; 50.0 \%)$; with prevalence of the brown color $(11 ; 91.6 \%)$. The level of education ranged from incomplete primary education to higher education; however, the predominant was complete primary education $(4 ; 33.3 \%)$. The monthly income of most of them was up to a minimum wage (11; 91.6\%), and their professions were housewives $(10 ; 83.3 \%)$, a farmer (8.3\%) and a nutritionist (8.3\%). As for housing, six (50.0\%) lived in rented houses and the other half (50.0\%) in their own homes; located in the metropolitan region of Fortaleza $(6 ; 50.0 \%)$ and in the interior of Ceará (6; 50.0\%).

The majority of the mothers $(11 ; 91.6 \%)$ reported not having used teratogens, such as tobacco, alcohol and illicit drugs and seven reported an infectious process during pregnancy $(58.3 \%)$ but they were unaware of ZIKV diagnosis in pregnancy. Seven women (58.3\%) had performed between six and 15 prenatal visits; five had planned the pregnancy (41.6\%). The majority were multiparous $(8 ; 66.6 \%)$; and nine (75.0\%) had had cesarean deliveries.

Among the 12 children with microcephaly, seven (58.3\%) were males and were between 12 and 26 
months old. Of these, half had had a prenatal diagnosis and the other half, postnatal diagnosis The majority (11; 91.6\%) was undergoing follow-up/treatment with a multiprofessional team.

The presentation of the results, after the content analysis process, occurred through three categories of analysis: The moment of diagnosis: being the mother of a special child; Getting to know microcephaly: the unknown; and Living with the disease: full dedication, mothering.

\section{The moment of diagnosis: being the mother of a special child}

In the first category, the participants talked about the moment they received the diagnosis of microcephaly of their children and reported that it occurred in the pre- or postnatal periods, as observed in the speeches: It was only when he was born and it was normal, it was normal because I did not know what microcephaly was yet. I only knew when the doctor came to explain to me; so I got a little shocked, but I treated him normally (Pearl). It was in my fourth month of gestation, it was kind of a shock, but I was already expecting because I had had the Zika virus infection and I had already researched about the consequences of the ZIKV, so I am very calm, but it was a shock (Moonstone). I only knew that she had microcephaly when she was born, which was on April 15, 2016, because at first the doctor said her head was not growing, he did not say the reason and that she was going to be born with a problem (Jade).

Reflecting on the exact moment of diagnosis of a disease such as microcephaly and the consequences, in the short and long term, generates the perception that it is a moment of great suffering for these mothers, accompanied by feelings such as fear, sadness, crying, fright and even denial. I was devastated because of the problem with which she was going to be born, so I got upset. I kept crying all the time, I cried day and night, day and night (Olivine). It was a shock, but then we take it normally (Blue Tourmaline). I did everything, I had the greatest care in the world, I paid for private ultrasound... when I got to the hospital to have him, the doctor said he had microcephaly... for me, the world collapsed, because you expect your son to be born healthy, when the doctor said, you child has "micro", there for me, the world collapsed, but because I saw my son as normal, and at the same time I saw him as a special baby (Emerald). Sad to know that she is so small with so much problems, that's how it was. About her development, she will be slow to talk, to sit, everything will be slower. Yeah, but it was only in the beginning, now I am finding it natural. For me, she has no problem (Turquoise).

\section{Getting to know microcephaly: the unknown}

In the second block, the knowledge of the participating mothers about microcephaly was investigated. The participants presented heterogeneous answers on the subject. While some mothers understood the meaning of the term, others had a wrong understanding about the term or had no satisfactory understanding about the disease. One of the mothers commented that the child was "normal", even with microcephaly. It is caused by the dengue mosquito. I know that it leaves many sequelae, because there is microcephaly from various infections, urinary infection causes microcephaly, toxoplasmosis causes microcephaly, but the Zika virus is the one that leaves more sequelae (Moonstone). A very complicated disease, there is a delay in the child's development, the child is dependent on the person until... many years. Some children do not walk, after five years they start to walk. Mine is one year and eight months old, she does not walk and does not sit (Blue tourmaline). It is a disease caused by the mosquito and it affects the brain, the development of the brain, so they have almost no movement (Turquoise). I do not know how to answer you right because I do not, I do not know (Agate). So... the doctor says, some say that he will walk, others say he will speak, but everything in his time, which is in God's time. So for me, this disease here is nothing bad, my son never had to do surgery, he never had to take medication, he came for his medical visit. Thank God, his illness is normal child's disease, fever, dentition, these things. But about the disease, I have nothing to say (Emerald).

Regarding the guidelines received on the care to be performed with the child, most mothers responded that they received varied information/guidance, such as medication, food, hygiene, frequency of consultation with specialists, use of toys as a form of stimula- 
tion, but others said they needed more guidance. These instructions also occurred in the form of lectures and through home visits by professionals. Every month, when I go to the doctor's office, the doctors guide me even more. They talk more about food... hygiene, about a lot of things (Ruby). Yes, like on the physiotherapy care for us not to lose it, on food, they cannot eat everything, but my son eats everything, he just does not eat stone because he does not know how to chew it (laughs). They are not normal children, they have to have a schedule for everything (Emerald)....we have physical therapy... they take the afternoon to explain how to take care of them at home... they give us lectures, books, visit us at home, guides on which toy to buy. They do their best for us to adapt our lives with them. (Moonstone). It was very basic; they only said I had to do the treatment for him to develop more (Pearl). No, they've only asked us to do physiotherapy at home, that's all (Sapphire).

\section{Living with the disease: full dedication, mothering}

In the last category, we sought to know the perspectives of these mothers for their future and their children's, so it was observed in the speeches that the daily care of the mother with the child with microcephaly brought obstacle to daily activities related to the house and to themselves, since they dedicated themselves exclusively to these children. Because I have to be with her all the time in my arms. She does not sit down, I have to keep an eye on her... it messes everything up. My daily routine with her is just to pay attention to her, which is what she wants (Sapphire). It's me giving the medicine to him and giving him food, because he chokes with everything and lately he has been crying, becoming all purple. So, in my day to day, the worst thing is this, and giving him water because he chokes (Agate). Well, I think it's preparing lunch with him on my arms... I have to wait for someone to show up so I can take a shower, because he does not stay any place, he does not stay alone, he does not stay in a hammock, he does not stay any place; he only stays in my arms, it's difficult, that's all. Everything has to be with him or depends on others (Jasper).

In the question that addressed the perception of the women about the motor development of the child, it was noticed that most perceived that the children present changes. Others, even knowing about the child's disease, denied this fact, stating that the child was normal, a reaction that is believed to be manifested in the face of an unexpected situation, about which they have no control. Spirituality has also been highlighted in some lines. Of course, we see it... of course we see, I think anyone can see it (Moonstone). Sure (Diamond). Now he's talking Grandma, I put him on the walker and he's already moving the walker away, he's pulling away, he's stretching, but he ... if God's will is done for him to walk, he'll walk, but whatever it is, it's good. For me, God knows what he does. He's fine, the physiotherapists working with him say he's developing very well. So, for me, what matters is what they say (Emerald). No, for me she is normal, no changes (Ruby).

When reflecting on the exteriorized thinking of each mother through the speeches, regarding the future of the child, we perceived that this is a difficult subject, in which the mothers, before answering to the question, were thoughtful and even moved. The following accounts relate to uncertainties as to the future of the child. Some mothers reported not thinking about the future, perhaps because they had no hope, while those who believed in the recovery of the child were aware that it would be a slow and arduous journey. I do not think about the future, I think about today (Diamond). I do not think about the future, one thing I do not think is in the future (Pearl). I imagine several things, that she will be in a wheel chair, I do not know... I imagine that she, the work will be harder (Olivine). To the future... I do not know, I hope he is walking, studying, doing everything a normal child does (Blue Tourmaline).

\section{Discussion}

Each individual has particularities, so that experiences, even occurring in the same context, can be interpreted differently. It was observed in some statements that the birth of a child with microcephaly was not a challenge, and that there were no prospects, since for some mothers, they had only a child with some limitations, but that he/she would normally evolve in the future. Therefore, the results obtained in this study cannot be extended to all mothers of children with microcephaly, and it is not possible to generalize the meaning regarding the proposed objective.

In the work of the multiprofessional team with 
children affected by microcephaly, contact with mothers is indispensable, and little research has been directed at investigating the transformations of the maternal universe after the diagnosis of a malformation, such as the emotional impact on quality of life and coping strategies. Through the results of this study, it is important to strengthen the planning of support networks for the children's families, with strategies to host these mothers through rounds of conversations, in which they can receive guidance from all the staff, seeking to understand and solve the greatest doubts and needs, improving self-care and child care.

A study conducted in Salvador, Brazil, with children with microcephaly due to ZIKV identified mothers as the primary caregivers of these children, but presented a different profile for these women, who were between 25 and 35 years old, were single and had better level of schooling than those investigated in the present study, with most women having complete high school. This different profile of age, marital status and schooling may occur due to differences in socioeconomic conditions in the states of study, although both are located in the Northeast region of Brazil ${ }^{(9)}$.

Prenatal screening is essential in the discovery of microcephaly due to ZIKV, so that, unlike other studies that show that the diagnoses occurred in the pre- and perinatal period, in the present study, women were diagnosed before and after childbirth, with no data recorded in the peripartum period. Prenatal diagnosis is important so that mothers and families are prepared to receive a child who will need special care and will require additional costs. Also, the prenatal investigation allows the differential diagnosis of other environmental teratogens that may also cause this disease, such as drug use and the occurrence of infections, which did not occur in this study ${ }^{(9-10)}$.

A study about the experience of mothers in the care of children with type 1 diabetes revealed that the moment of diagnosis was the most shocking and of greatest suffering for the mothers, in which they experienced mixed feelings, characterizing a phase of crisis, with destabilization, uncertainties and acceptance of the disease that conceives the process of care without fear. Another research on the experience of parents after the diagnosis of microcephaly by ZIKV observed that fathers and mothers can go through a moment of denial, looking at the children as they had no disease. After denial, an initial phase of destabilization occurs, followed by an adaptation, in which the parents end up accepting the child's diagnosis and perceiving the child's needs, thus establishing a relationship of affection and patience ${ }^{(7,11-12)}$.

After the diagnosis, mothers should be guided on the repercussions imposed by the diagnosis, since most of them do not have the actual knowledge about the child's condition, the causes and the possible consequences, as observed in this study. Research on children with chronic diseases found that the mothers showed partial knowledge about the child's condition, not understanding what caused the occurrence of the clinical condition, when it occurred and the motor and cognitive repercussions, which corroborates the present study ${ }^{(7,13)}$.

In the midst of so much pain, denial and suffering, mothers often show a great degree of overcoming and strengthening of resilience, through which these women raise self-esteem and regain autonomy, either through professional support groups, from family or through spirituality. The feeling of spirituality exposed by the mothers in this study is based on the belief of a higher power capable of overcoming all challenges; it is a form of parental coping in face of specific and chronically stressful situations, such as a congenital malformation ${ }^{(14-15)}$.

Due to the complexity of the picture presented by children with microcephaly, these need the professional assistance provided through multiprofessional support. For this purpose, professionals work in groups and each with their discipline, so that the child and the family are contemplated globally. In this study, the mothers emphasized the importance of the nurse and the physiotherapist, professionals who are part of 
the multiprofessional team that follow the families investigated. The work of these professionals provides adequate support to the family in face of their needs as they help families, collaborate with the maximum clarification about the disease, guide, accompany and stimulate the development acquisitions in order to minimize the repercussions caused by the disease changes $^{(5,16)}$.

Some parents of children with disabilities expressed positive perspectives in the hope of healing and, despite not knowing what to expect in the future, they want the child's improvement, regardless of the severity of the illness. The uncertainties about tomorrow prevail, as well as the doubt about the circumstances in which the children will develop and in what possibilities mothers will exercise the maternity. However, despite all these challenges, women show themselves to be survivors, resilient and fighters ${ }^{(17-18)}$.

\section{Conclusion}

The unexpected diagnosis of microcephaly brings limitations for mothers, with a complete change of routine and feelings of fear and insecurity. Multiple emotions were also observed in the face of this moment, such as non-acceptance, frustration and hope. The women participating in the study showed great difficulties in relation to the limitations of the child and to only partial knowledge about the child's disease, despite receiving guidance from the multiprofessional health team.

\section{Collaborations}

Campos MMMS and Sousa TC contributed to the conception and design, analysis and interpretation of data. Teixeira GP and Chaves KYS collaborated with article writing and relevant critical review of intellectual content. Araújo MVUM and Sousa MR assisted in the final approval of the version to be published.

\section{References}

1. Schuler-Faccini L, Ribeiro EM, Feitosa IML, Horovitz DDG, Cavalcanti DP, Pessoa A, et al. Possible association between Zika virus infection and microcephaly - Brazil, 2015. Morb Mortal Wkly Rep [Internet]. 2016 [cited 2018 Jun 7];65(3):5962. Available from: https://www.cdc.gov/mmwr/ volumes $/ 65 / \mathrm{wr} / \mathrm{pdfs} / \mathrm{mm} 6503 \mathrm{e} 2 . \mathrm{pdf}$

2. Flor CJDRV, Guerreiro CF, Anjos JLM. Neuropsicomotor development in children with microconfalia associated with Zika virus. Rev Pesq Fisio. 2017; 7(3):313-8. doi: http://dx.doi. org/10.17267/2238-2704rpf.v7i3.1386

3. Ventura CV, Maia M, Ventura BV, Linden VVD, Araújo EB, Ramos RC, et al. Ophthalmological findings in infants with microcephaly and presumable intra-uterus Zika virus infection. Arq Bras Oftalmol. 2016; 79(1):1-3. doi: http://dx.doi. org/10.5935/0004-2749.20160002

4. Marinho F, Araújo VEM, Porto DL, Ferreira HL, Coelho MRS, Lecca RCR et al. Microcephaly in Brazil: prevalence and characterization of cases from the Information System on Live Births (Sinasc), 2000-2015. Epidemiol Serv Saúde. 2016; 25(4):701-12. doi: http://dx.doi.org/10.5123/ s1679-49742016000400004

5. Vagas A, Saad E, Dimech GS, Santos RH, Sivini MAVC, Albuquerque LC, et al. Characteristics of the first cases of microcephaly possibly related to Zika virus reported in the Metropolitan Region of Recife, Pernambuco State, Brazil. Epidemiol Serv Saúde. 2016; 25(4):691-700. doi: http://dx.doi. org/10.5123/S1679-49742016000400003

6. Rego S, Palacios M. Ethics, global health and Zika virus infection: a view from Brazil. Rev Bioét. 2016; 24(3):430-4. doi: http://dx.doi. org/10.1590/1983-80422016243141

7. Oliveira MC, Sá SM. The parental experience after Zika virus microcephaly diagnosis: a case study. Rev Pesq Fisio. 2017; 7(4):64-70. doi: http:// dx.doi.org/10.17267/2238-2704rpf.v7i4.1602

8. Minayo MCS. O desafio do conhecimento: pesquisa qualitativa em saúde. São Paulo: Hucitec; 2014. 
9. Gonçalves AE, Tenório SDB, Ferraz PCS. Socioeconomic aspects of genitors of children with microcefalia related to Zika Virus. Rev Pesq Fisio. 2018; 8(2):155-63. doi: http://dx.doi. org/10.17267/2238-2704rpf.v8i2.1865

10. Brunoni D, Blascovi-Assis SM, Osório AAC, Seabra AG, Amato CAH, Teixeira MCTV et al. Microcephaly and other Zika virus related events: the impact on children, families and health teams. Ciênc Saúde Coletiva. 2016; 21(10):3297-302. doi: dx.doi. org/10.1590/1413-812320152110.16832016

11. Martins EMC, Ataíde MBC, Silva DMA, Frota MA. Experience of mothers in the care of children with type 1 diabetes. Rev Rene [Internet]. 2013 [cited Jun 13, 2018]; 14(1):42-9. Available from: http://www.periodicos.ufc.br/rene/article/ view/3324/2562

12. Barros SMM, Monteiro PLM, Neves MB, Maciel GTS. Fortalecendo a rede de apoio de mães no contexto da síndrome congênita do vírus zika: relatos de uma intervenção psicossocial e sistêmica. Nova Perspect Sist [Internet]. 2017 [citado 2018 jun 13]; 26(58):38-59. Disponível em: http://pepsic. bvsalud.org/pdf/nps/v26n58/n26a04.pdf

13. Cerqueira MMF, Alves RO, Aguiar MGG. Experiences in the therapeutic itineraries of mothers of children with intellectual disabilities. Ciênc Saúde Coletiva.2016; 21(10):3223-32. doi: http://dx.doi. org/10.1590/1413-812320152110.17242016
14. Guerra CS, Dias MD, Ferreira Filha MO, Andrade FB, Reichert APS, Araújo VS. From the dream to reality: experience of mothers of children with disabilities. Texto Contexto Enferm. 2015; 24(2):459-66. doi: dx.doi.org/10.1590/010407072015000992014

15. Silva EHP, Girão ERC, Cunha ACB. Father coping face to the congenital malformation of son before and after the birth. Estud Pesq Psicol [Internet]. 2016 [cited 2018 Jun 13];16(1):180-99. Available from: http://pepsic.bvsalud.org/scielo.php?script=sci_ arttext\&pid=S1808-42812016000100011

16. Medeiros VAB, Bezerra INS, Alves LT, França AMB. Assistência de enfermagem ao neonate com microcefalia. Ciên Biol Saúde Unit [Internet]. 2018 [cited 2018 oct 18]; 4(2):67-76. Disponível em:https://periodicos.set.edu.br/index.php/ fitsbiosaude/article/view/5109/2782

17. Galli B. Where is the right to abortion? Comment on the documentary Zika, The Film. Cad Saúde Pública. 2016; 32(6):1-2. doi: http://dx.doi. org/10.1590/0102-311xes010616

18. Pedroso CNLS, Félix MA. Percepção dos pais diante do diagnóstico e da abordagem fisioterapêutica de crianças com paralisia cerebral. Rev Ciênc Saúde [Internet.] 2014 [cited 2018 Jun 10];7(2):6170. Available from: http://revistaseletronicas. pucrs.br/ojs/index.php/faenfi/article / view/16464/11802 